\title{
Article
}

\section{Fire toxicity - The elephant in the room?}

\author{
Stec, Anna A
}

Available at http://clok.uclan.ac.uk/22881/

Stec, Anna A ORCID: 0000-0002-6861-0468 (2017) Fire toxicity - The elephant in the room? Fire Safety Journal, 91 . pp. 79-90. ISSN 0379-7112

It is advisable to refer to the publisher's version if you intend to cite from the work.

http://dx.doi.org/10.1016/j.firesaf.2017.05.003

For more information about UCLan's research in this area go to

http://www.uclan.ac.uk/researchgroups/ and search for <name of research Group>.

For information about Research generally at UCLan please go to http://www.uclan.ac.uk/research/

All outputs in CLoK are protected by Intellectual Property Rights law, including Copyright law. Copyright, IPR and Moral Rights for the works on this site are retained by the individual authors and/or other copyright owners. Terms and conditions for use of this material are defined in the policies page.

\section{CLoK}

Central Lancashire online Knowledge www.clok.uclan.ac.uk

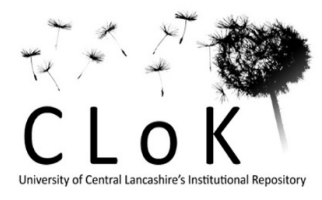




\title{
Fire Toxicity - the Elephant in the Room?
}

\author{
ANNA A STEC, \\ Centre for Fire and Hazards Sciences, \\ School of Physical Sciences \& Computing, \\ University of Central Lancashire, \\ Preston, Lancashire, PR1 2HE, UK
}

\section{ABSTRACT}

Fire toxicity is the largest cause of death and injury from unwanted fires, yet it is the least well studied area of fire science and engineering. Fire toxicity increases by factors up to 50, as the fire becomes underventilated. This has proved difficult, but not impossible, to replicate in a controlled way on a bench-scale. Clear correlations have been observed between the stoichiometric equivalence ratio, and the yields of the major asphyxiants, carbon monoxide and hydrogen cyanide. In addition, irritant components of fire effluents, which have an instantaneous effect, can incapacitate fire victims, trapping them in a fire. However, the longer term toxicants present in fire effluents, such as the carcinogenic polycyclic aromatic hydrocarbons, and the microscopic particulates which result from their agglomeration are probably responsible for hundreds or thousands more deaths than the acute asphyxiants and irritants.

KEYWORDS: polymers, plastics, fire, toxicity, hazard evaluation, large scale testing.

\section{INTRODUCTION}

The toxicity of fire effluents is known to be the biggest cause of death injury from unwanted fires [1]. Compared with natural materials (wood, wool, cotton, leather, etc.), widely used synthetic polymers (derived from oil) burn more quickly; they also generate more smoke and toxic effluents, particularly when compounded with halogenated flame retardants [2,3]. Although the overall number of fire deaths in the UK has decreased [4], there has been a progressive shift in cause of death from 'burns' to 'overcome by toxic gas or smoke' ("Smoke") from 1955-2015 (Fig. 1). The rise in the fire toxicity injuries is even more dramatic. In many parts of Europe fire deaths and injuries are still rising; for example, recent Polish fire deaths and injuries show twice the UK's number of fatalities per head of population while Latvia, Estonia and Lithuania have a factor of 10 more fire deaths $[5,6,7]$.
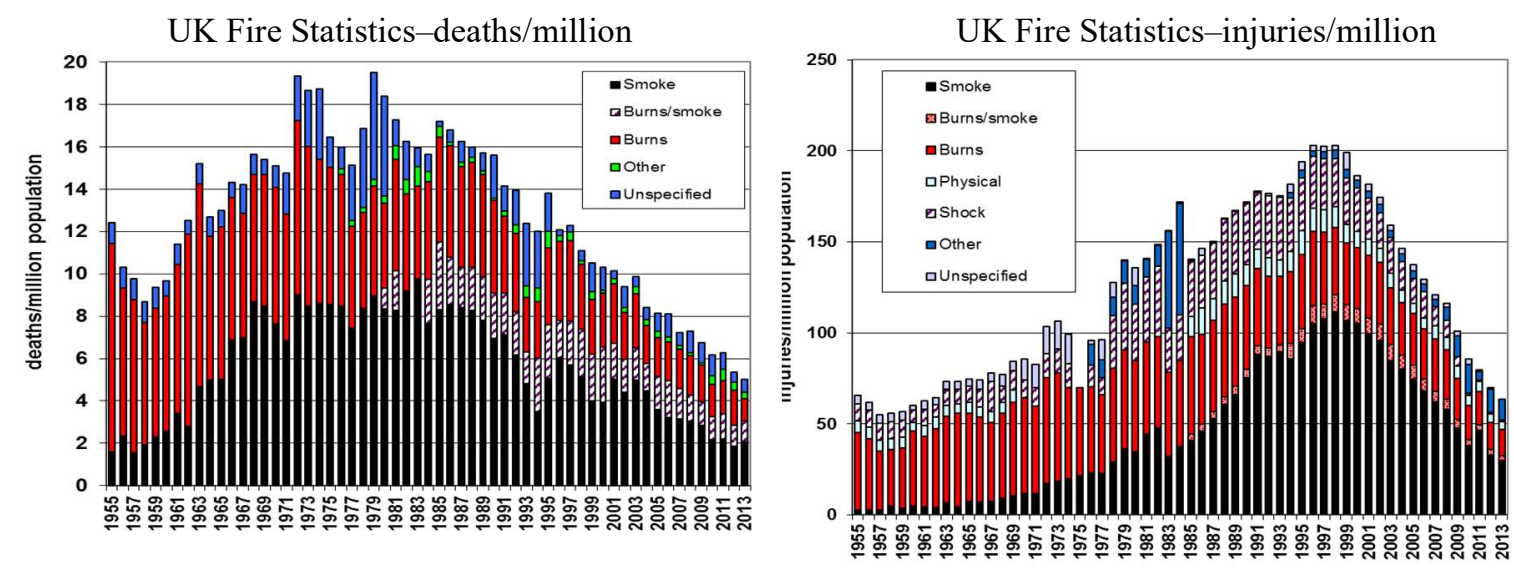

Fig 1. Fire deaths and injuries in the UK (1955-2013). 
The overwhelming majority of fire deaths $80 \%$ [1] occur in people's homes, which are less regulated than public buildings or transport. Findings from a number of dwelling fire death cases over the period 20032011 in Mazowieckie region (Poland) showed the majority of fire deaths were in the room of origin, of whom around half were found close to burned upholstered furniture. By far the majority of victims had inhaled sufficient smoke, carbon monoxide (CO) and other gases to cause incapacitation and $80 \%$ were reported as having soot in their airways. Approximately $60 \%$ had inhaled sufficient CO, smoke and other gases to have contributed to or been the main cause of death [8].
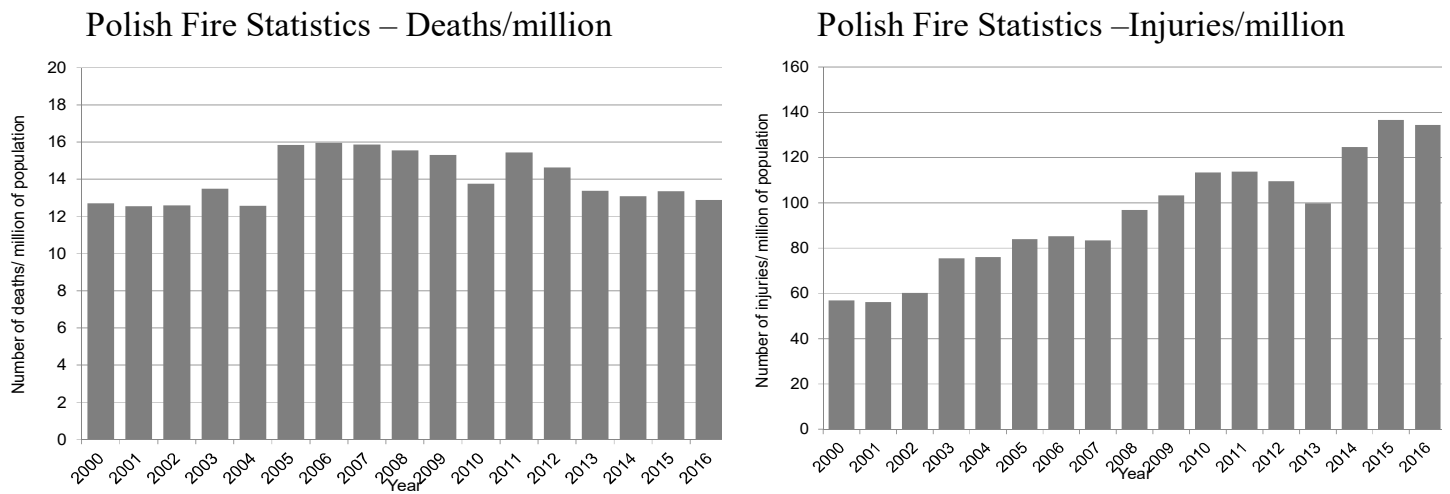

Fig 2. Fire deaths and injuries in Poland (2000-2016) [8].

The asphyxiants carbon monoxide (CO) and hydrogen cyanide (HCN), are known to cause the death of most fire victims in the short term. $\mathrm{CO}$ and $\mathrm{HCN}$ yields are much higher in under-ventilated flaming, which is more difficult to replicate on a bench scale. The recent findings that firefighters have twice the rate of cancer deaths of the civilian population highlights the significance of carcinogens as longer-term fire toxicants. There is currently no requirement to quantify carcinogens from burning materials for products, and no restriction on products emitting lethal quantities of carcinogens during a fire.

Further, it is becoming increasingly clear that airborne particulates are resulting in a very large loss of human lives. In 2014, 367000 European lives were lost from inhalation of airborne particulates [9]. These deaths are currently being blamed almost exclusively on diesel vehicles. However, a pioneering report from Sweden in 1998 [10] demonstrated that unwanted fires (as distinct from power stations, urban incinerators and engines etc., and also excluding wildland fires) were responsible for a disproportionately large amount of the emissions of polycyclic aromatic hydrocarbons (PAH) and atmospheric particulates; the emission of particulates and unburnt hydrocarbons from one tonne of fuel from an unwanted fire is equivalent to that from burning almost 200 tonnes of solid fuel in a power station; they estimated that in Sweden 1000 tonnes of particulates were emitted by fires, 4000 tonnes by power stations and 9000 tonnes by road transport. In their follow-up study they quantified the emissions of PAH in Sweden from unwanted fires as $7 \pm 5$ tonnes [11]. Alongside these two reports of $\mathrm{PAH} /$ particulate emissions from actual or reproduced unwanted fires, recent evidence shows that wood burning stoves, which are much closer to unwanted fires than burning coal, oil, diesel, petrol or gas, emit far more PAH and the most dangerous $\mathrm{PM}_{2.5}$ particulates[12-13]. The heterogeneity of unwanted fires and their high burning rates and low combustion efficiency are therefore highly likely to produce particles of widely different, and potentially much greater toxicity than those from diesels or other combustion.

Recently there has been a resurgence of interest in fire toxicity. This has been driven by three factors:

- The progressive replacement of prescriptive codes by performance based design approaches to ensuring fire safety.

- The development of tools to make meaningful assessments of fire toxicity.

- The gradual recognition that the problem of fire toxicity had not been addressed by the emphasis on heat release in fire safety engineering. 


\section{FIRE SCENARIOS}

The factors affecting fire gas toxicity $[14,15,16]$, have been systematically determined in terms of the yields of toxic gases and other combustion products (smoke, particulates) $[17,18]$ as a function of fire condition for a wide range of polymers. This requires painstaking analytical investigation to correlate the concentrations of individual toxicants in fire gases, obtained by interpretation of gas phase FTIR spectra, with those from complementary analyses (HPIC, spectrophotometry, chemiluminescence, NDIR, GC-MS, and wet chemical analysis) $[19,20]$. Indeed, the generation, sampling and quantification of fire effluents is in itself highly challenging work [21]. For many common materials carbon monoxide is not the only significant toxicant in fire gas (hydrogen cyanide from burning nylon [15], or hydrogen chloride from burning PVC are both produced in yields of greater toxicological significance) [22].

The steady state tube furnace has been developed from a little-used British Standard (BS 7990) into the first international standard (ISO TS 19700) for bench-scale measurement of fire toxicity [23], specifically as a tool for fire safety engineering. Its repeatability and reproducibility, have been quantified [24, 25], relating its yields to other national and international standards (the smoke chamber, ISO 5659 modified for toxicity measurements as ISO draft DIS 21489, the French railway test NF X 70-100, the US Fire Propagation Apparatus ASTM E2058, and DIN 53436) [26] and finally to comparable data from the limited data available from large scale tests [27, 28]. This work showed, for the first time, that under controlled conditions, robust quantification of fire toxicity was achievable.

Material composition, temperature and oxygen concentration are normally the most important [29]. The generalised development of a fire has been recognised, and used to classify fire growth into a number of stages, from smouldering combustion and early well-ventilated flaming, through to fully-developed underventilated flaming [30]. Although on some occasions smouldering (oxidative pyrolysis) can generate toxicologically significant quantities of effluent (for example smouldering cotton, or polyurethane foam), the rate of reaction, and hence the amount of toxic species generated will be small, so unlikely to affect anyone outside the immediate vicinity. Similarly, well-ventilated fires are generally small, so extinguishment or escape is still feasible, while the fire effluent moves across the ceiling above head height. However, as they grow, fires become ventilation controlled, and fires in enclosures such as buildings rapidly change from well-ventilated to under-ventilated (or vitiated). These fires are larger, and therefore produce greater volumes of effluent, affecting occupants over a much wider part of any building. While wellventilated fire scenarios are routinely used for assessment of flammability, because the object is to stop the fire growing to the out of control stage, where fire toxicity is concerned, the important fire stages are underventilated. There are two reasons for this:

1. The volume of effluent is much greater.

2. The yields of the major toxic products (carbon monoxide and hydrogen cyanide, and other products of incomplete combustion) will be much greater [2,20].

The most significant differences in fire conditions arise between flaming and non-flaming combustion. The high reactivity of the radicals in the flame drive the oxidation of fuel forward as far as it can go, with the available oxygen. Once flaming combustion is established, the fuel/air ratio has the greatest effect the yields. As a fire in a building develops, the temperature increases and oxygen concentration decreases. Research predicting the carbon monoxide evolution from flames of simple hydrocarbons, reviewed by Pitts [31], has shown the importance of the equivalence ratio, $\phi$, for predicting the $\mathrm{CO}$ yield from the oxygen depletion in flaming conditions (Eq. 1).

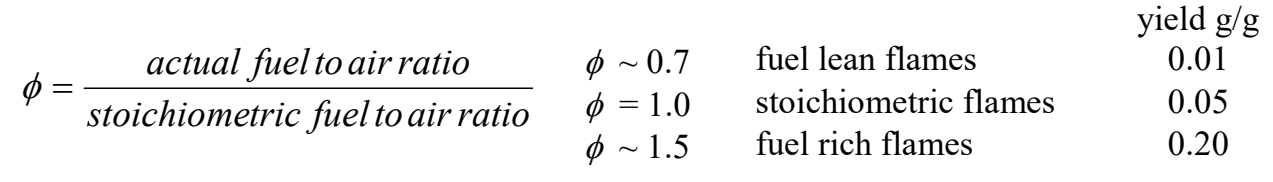

In a fully developed fire, with low ventilation, $\phi$ can be as large as 5 []. For many hydrocarbon polymers, $\mathrm{CO}$ yield increases rapidly with increase in $\phi$, almost independent of polymer [32]. In addition, a close 
correlation between $\mathrm{CO}$ formation and $\mathrm{HCN}$ formation has been established in full-scale fire studies [33, 34], as the formation of both species appear to be favourable under the same poorly ventilated fire conditions.

\section{Fire Hazards}

Fires usually start small, and grow slowly at first. Lethal fires often involve smouldering furnishing (bed or chair) where there is a gradual increase in the local concentrations of smoke and toxic gases. During this time carbon monoxide $(\mathrm{CO})$ and a large number of organic products are generated in the smoke. This can incapacitate victims or put them into a deep sleep so they do not escape. Once flaming starts, these products of incomplete combustion are oxidised to carbon dioxide $\left(\mathrm{CO}_{2}\right)$ and water, and the effluent toxicity of the well-ventilated fire decreases briefly. However, if there is enough fuel, the fire quickly grows until it is limited by the availability of oxygen: it becomes under-ventilated. This results in an increase in smoke, reducing visibility as the asphyxiant (oxygen depriving) gases $(\mathrm{CO}$, and hydrogen cyanide $(\mathrm{HCN})$ ); irritant gases (hydrogen chloride $(\mathrm{HCl})$, hydrogen bromide $(\mathrm{HBr})$, nitrogen dioxide $\left(\mathrm{NO}_{2}\right)$, ammonia $\left(\mathrm{NH}_{3}\right)$, acrolein $\left(\mathrm{CH}_{3} \mathrm{CHO}\right)$ etc.); and deep lung irritants and particulates are generated. $\mathrm{CO}$ and $\mathrm{HCN}$ concentrations increase by factors of 10 to 50 with under-ventilation, are far more dangerous than the lack of oxygen, and untenable conditions rapidly develop.

Table 1. Hazards from fire, typical origins, and their effect on humans

\begin{tabular}{|c|c|c|c|}
\hline Toxic products & Origin & Effects & $\begin{array}{c}\text { Tenability/ } \\
\text { Thresholds } \\
\text { Limits } \\
\text { (within } 30 \text { min) } \\
\end{array}$ \\
\hline $\begin{array}{l}\text { Halogenated } \\
\text { acids } \\
(\mathrm{HCl}, \mathrm{HBr}, \mathrm{HF})\end{array}$ & $\begin{array}{l}\text { Polyvinyl chloride, } \\
\text { Halogenated Flame } \\
\text { Retardants }\end{array}$ & Respiratory tract irritation & $\begin{array}{l}100 \mathrm{ppm} \text { to } \\
1000 \mathrm{ppm}\end{array}$ \\
\hline $\begin{array}{l}\text { Nitrogen dioxide } \\
\left(\mathrm{NO}_{2}\right)\end{array}$ & $\begin{array}{l}\text { High temperature combustion } \\
\text {-severe fires, car exhausts }\end{array}$ & $\begin{array}{l}\text { Respiratory tract irritation } \\
\text { Mucus membrane irritant }\end{array}$ & $170 \mathrm{ppm}$ \\
\hline Smoke & $\begin{array}{l}\text { Organic material forming tar } \\
\text { droplets or soot particles } \\
\text { (especially if carbon rich or } \\
\text { under-ventilated) }\end{array}$ & $\begin{array}{l}\text { Airway Obstruction, } \\
\text { Visual obscuration }\end{array}$ & $\begin{array}{l}0.33 \mathrm{OD} \cdot \mathrm{m}^{-1} \\
\text { (OD is Optical } \\
\text { Density) }\end{array}$ \\
\hline $\begin{array}{l}\text { Oxygen } \\
\text { depletion }\left(\mathrm{O}_{2}\right)\end{array}$ & Combustion/Pyrolysis & Asphyxia, Laryngotraheitis & $10-12 \%$ \\
\hline $\begin{array}{l}\text { Carbon } \\
\text { monoxide }(\mathrm{CO})\end{array}$ & $\begin{array}{l}\text { Incomplete combustion of } \\
\text { any organic material }\end{array}$ & $\begin{array}{l}\text { Functional asphyxia, } \\
\text { narcosis tissue hypoxia, } \\
\text { organ failure, death }\end{array}$ & $5700 \mathrm{ppm}$ \\
\hline $\begin{array}{l}\text { Hydrogen } \\
\text { Cyanide }(\mathrm{HCN})\end{array}$ & $\begin{array}{l}\text { Polyurethane, Polyamides, } \\
\text { Acrylics (polyacrylonitrile), } \\
\text { Wool, etc. }\end{array}$ & $\begin{array}{l}\text { Cellular Asphyxia, Tissue } \\
\text { hypoxia, organ failure, death }\end{array}$ & $165 \mathrm{ppm}$ \\
\hline
\end{tabular}

\section{ASSESSMENT OF FIRE TOXICITY}

Exposure to toxic fire effluents can initially lead to a combination of physiological and behavioural effects of which physical incapacitation, loss of motor coordination and disorientation, which may be lifethreatening, because they can impair safe escape. Furthermore, survivors of a fire may experience postexposure effects, complications and burn injuries, leading to death or long term impairment. In the last decade, the major effects, such as incapacitation or death, may be predicted by quantifying the fire effluents in different fire conditions in small-scale tests, using only chemical analysis, without recourse to animal exposure.

The general approach in generating toxic potency data from chemical analysis is to assume additive behaviour of individual toxicants, and to express the concentration of each as its fraction of the lethal concentration for $50 \%$ of the population for a 30 minute exposure $\left(\mathrm{LC}_{50}\right)$. Summing these contributions 
generates a fractional effective dose (FED). An FED equal to one indicates that the sum of concentrations of individual species will be lethal to $50 \%$ of the population over a 30 minute exposure. This approach uses existing rat lethality data, as described in ISO 13344 [35]. An equation has been developed for the estimation of the FED for lethality from the chemical composition of the environment in the physical fire model, beginning with the precept that the fractional lethal doses of most gases are additive, as developed by Tsuchiya [36].

The Purser model (Eq. 2) uses the concentration of each toxicant as a ratio of its lethal concentration, then multiplies it by $\mathrm{V}_{\mathrm{CO}_{2}}$ a factor for $\mathrm{CO}_{2}$ driven by hyperventilation, therefore increasing the $\mathrm{FED}$ contribution from all the toxic species. It also incorporates an acidosis factor A to account for toxicity of $\mathrm{CO}_{2}$ in its own right.

$$
\begin{aligned}
& \mathrm{FED}=\left\{\frac{[\mathrm{CO}]}{\mathrm{LC}_{50, \mathrm{CO}}}+\frac{[\mathrm{HCN}]}{\mathrm{LC}_{50, \mathrm{HCN}}}+\frac{[\mathrm{AGI}]}{\mathrm{LC}_{50, \mathrm{AGI}}}+\frac{[\mathrm{OI}]}{\mathrm{LC}_{50, \mathrm{OI}}} \ldots\right\} \times \mathrm{V}_{\mathrm{CO}_{2}}+\mathrm{A}+\frac{21-\left[\mathrm{O}_{2}\right]}{21-5.4} \\
& \mathrm{~V}_{\mathrm{CO}_{2}}=1+\frac{\exp \left(0.14\left[\mathrm{CO}_{2}\right]\right)-1}{2}
\end{aligned}
$$

$[\mathrm{AGI}]$ is the concentration of acid gas irritants

[OI] is the concentration of organic irritants

$\mathrm{A}$ is an acidosis factor equal to $\left[\mathrm{CO}_{2}\right] \times 0.05$.

$\left[\mathrm{CO}_{2}\right]$ and $\left[\mathrm{O}_{2}\right]$ are expressed as percentage, by volume.

Other gas concentrations must use the same units as their $\mathrm{LC}_{50}$ data.

To illustrate how this translates into a toxic effect, the major LDPE, PMMA, PS, PA 6.6, and PVC product yields, obtained from the steady state tube furnace, have been translated into an overall estimation of the fire effluent toxicity, using the methods described in ISO 13344 indicating the contribution of each toxicant towards the overall fire hazard. The toxicity is expressed as FED for a fuel mass charge concentration of 20 $\mathrm{g} / \mathrm{m}^{3}$.

Most polymers without heteroatoms follow the trend shown by LDPE and PMMA of fire toxicity increasing from a very low value in well-ventilated conditions, to a much higher value in under-ventilated flaming. As can be seen from Fig. 3, there is large variation in FED values for materials containing chlorine or nitrogen. For well-ventilated tests, the largest FED value is for PVC. The FED is greater than 1, indicating the lethality of the diluted fire atmosphere over 30 minutes. PVC is one of the few materials to show a predicted combustion toxicity which is almost independent of the equivalence ratio, showing unusually high toxicity under well ventilated conditions. As an irritant gas, $\mathrm{HCl}$ will have the greatest effect of any toxic species. For under-ventilated fires, HCN from PA 6.6 makes the most significant contribution to the toxicity, and a high dependency on fire conditions is observed. HCN generated during small and large under-ventilated flaming tests makes the most significant contribution to the toxicity. For PA 6.6 in under-ventilated conditions, and for $\mathrm{PVC}, \mathrm{HCN}$ and $\mathrm{HCl}$ make the greatest contribution to the final $\mathrm{FED}$, showing the importance of two toxicants other than CO. PMMA, LDPE and PS are hydrocarbons without any halogens or nitrogen, and this is reflected in FED values well below 1 for the well-ventilated fire scenario. The fire effluent from polystyrene has relatively low toxicity, and shows characteristically low dependence on fire conditions. The toxic contribution of CO under fuel-rich conditions is remarkably similar to those generated under fuel lean conditions, as shown in Fig. 3.

The equations in ISO 13344 only relate to lethality, or cause of death. However, many people fail to escape from fires because of the incapacitating effect of smoke (obscuring visibility) and its irritant components which cause pain, preventing breathing or reason for death. 


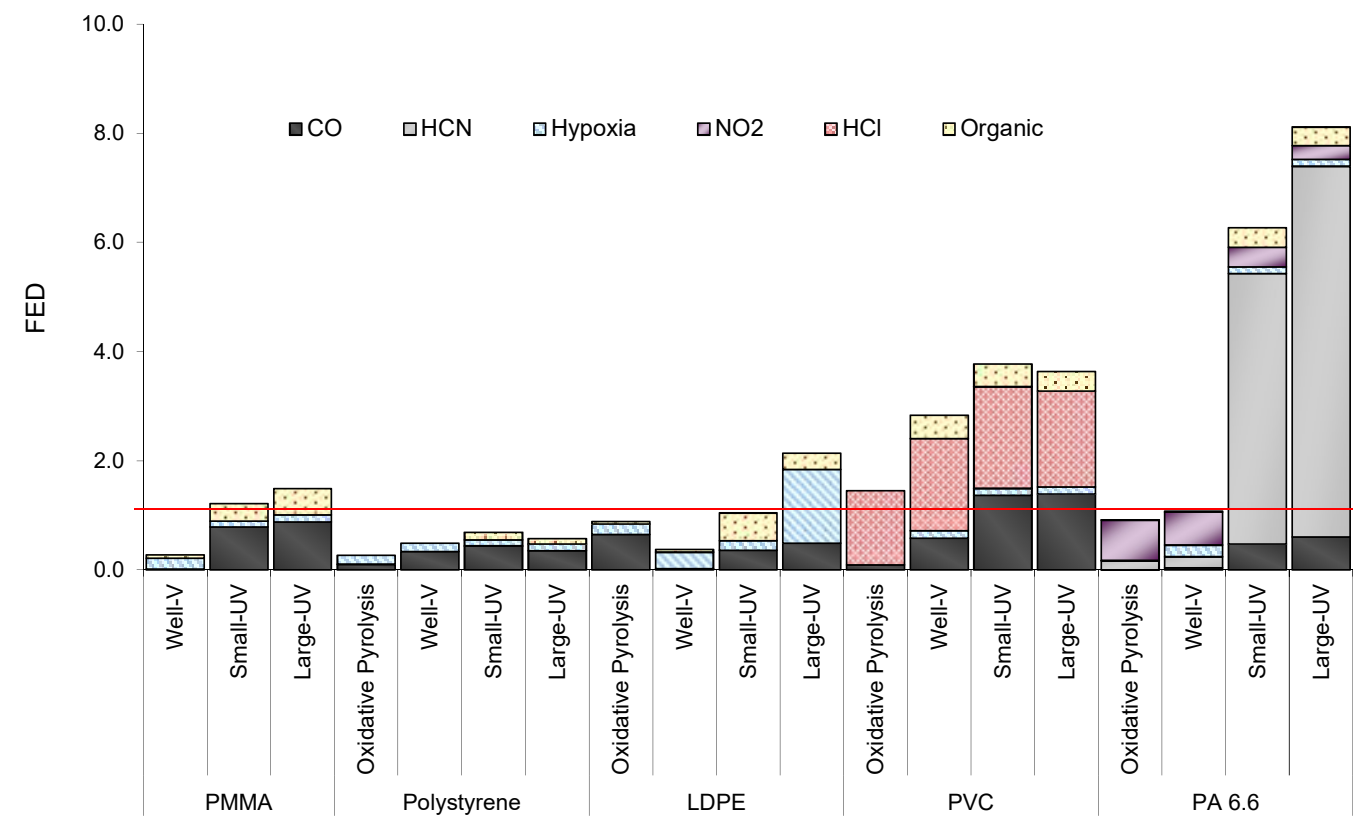

Fig. 3. FED assessments for common polymers using ISO 13344 [2].

ISO 13571 [37] considers the four major hazards from fire which may prevent escape (toxic gases, irritant gases, heat and smoke obscuration). It includes a calculation for prediction of incapacitation of humans exposed to fire effluents, indicating, in a non-normative appendix, that the effects of heat, smoke and toxicants may be estimated independently. Equations 3 and 4 have been taken from ISO 13571. They calculate the FED of asphyxiants, $\mathrm{CO}$ and $\mathrm{HCN}$, but without taking oxygen depletion or $\mathrm{CO}_{2}$ driven hyperventilation into account, and the Fractional Effective Concentration (FEC) of sensory irritants in the fire effluent which limit escape. Equation 3 represents the generally accepted case that there are only two significant asphyxiant fire gases, $\mathrm{CO}$ and HCN. The FED value is calculated using the exposed dose relationship (concentration-time product, $\mathrm{C} \cdot \mathrm{t}$ ) for $\mathrm{CO}$. The lethal $\mathrm{C} \cdot \mathrm{t}$ product corresponds to the incapacitating dose $\left(\mathrm{C} \cdot \mathrm{t}\right.$ ) for $\mathrm{CO}$ of $35000 \mu \mathrm{L} \mathrm{L} \mathrm{L}^{-1} \min$ (approximately equal to ppm min), equal to around 1170 ppm for 30 minutes exposure, and an exponential relationship for HCN (because incapacitation by $\mathrm{HCN}$ exposure does not fit a linear relationship). Since the concentration of fire effluents increases as a function of time, the input to the asphyxiation equation (3) is the concentration-time profile.

$\mathrm{FED}=\sum_{t_{1}}^{t_{2}} \frac{[\mathrm{CO}]}{35000} \Delta t+\sum_{t_{1}}^{t_{2}} \frac{\exp ([\mathrm{HCN}] / 43)}{220} \Delta t$

Since the effect of irritant gases is more or less instantaneous, only the concentration is required to predict incapacitation by irritants.

$\mathrm{FEC}=\frac{[\mathrm{HCl}]}{\mathrm{IC}_{50, \mathrm{HCl}}}+\frac{[\mathrm{HBr}]}{\mathrm{IC}_{50, \mathrm{HBr}}}+\frac{[\mathrm{HF}]}{\mathrm{IC}_{50, \mathrm{HF}}}+\frac{\left[\mathrm{SO}_{2}\right]}{\mathrm{IC}_{50, \mathrm{SO}_{2}}}+\frac{\left[\mathrm{NO}_{2}\right]}{\mathrm{IC}_{50, \mathrm{NO}_{2}}}+\frac{[\text { acrolein }]}{\mathrm{IC}_{50, \text { acrolein }}}+\frac{[\text { fomaldehyd e }]}{\mathrm{IC}_{50, \text { fomaldehyd e }}}+\sum \frac{[\text { irritant }]}{\mathrm{IC}_{50, \text { irritant }}}$

The fire toxicity of a material can also be expressed as a Material-LC $\mathrm{C}_{50}$, which in this case is the specimen mass $\mathrm{M}$ of a burning polymeric material which would yield an FED equal to one within a volume of $1 \mathrm{~m}^{3}$. The relation to the FED from the N-Gas model is given in Eq. 5.

Material $-\mathrm{LC}_{50}=\frac{M}{\mathrm{FED} \times V}$

where $V$ is the total volume of diluted fire effluent in $\mathrm{m}^{3}$ at STP. 
Unwanted fires will produce many more products of incomplete combustion, including particulates, carcinogens, such as polycyclic aromatic hydrocarbons (PAH), respiratory sensitizers such as isocyanates, and persistent, bioaccumulative and toxic (PBT) compounds such as polychloro- and polybromodibenzo dioxins and dibenzofurans (PCDD/F and PBDD/F) (“dioxins") from fuels containing halogens.

Volatile and Semi-Volatile Organic Compounds (VOCs/SVOCs): Complex mixtures of VOCs/SVOCs are generated as incomplete combustion products during accidental fires, and many of them are known to be significantly damaging to human health and the environment. Important examples of these compounds are benzene, styrene, and phenol, as these are all generally formed in the majority of fires [38]. Benzene is of particular toxicological significance as it is a precursor of carcinogenic polycyclic aromatic hydrocarbons (PAHs) as well as being a known carcinogen in its own right [38]. Their hydrophobic structures make them environmentally persistent and bioaccumulative in fatty tissues.

The irritant chemicals released in fires are formed during the pyrolysis and partial oxidation of materials, and the combinations of products from different materials are often remarkably similar [39, 40]. However, for many organic materials and particularly for simple hydrocarbon polymers such as polypropylene or polyethylene, the main pyrolysis products, which consist of various hydrocarbon fragments, are innocuous. Thus when polypropylene is pyrolysed in nitrogen the product such as ethylene, formaldehyde, acetaldehyde, styrene etc. are produced, and such an atmosphere was found to have no effect upon primates [41]. However, when these products are oxidized during nonflaming decomposition in air, some are converted to highly irritant products, and such atmospheres were indeed found to be highly irritant to both mice and primates. In reports of mouse exposure experiments, some fire retardant materials, which could be induced to flame only intermittently, with considerable smoke production, were found to produce atmospheres up to 300 times more irritant than the same polymer in its non-fire retardant state, which burned cleanly [42]. Table 2 shows some of more toxic, commonly encountered organic species in fire gas, with the concentration considered by NIOSH to be Immediately Dangerous to Life or Health (IDLH) [43].

Table 2. Common organo irritants found in fire gas with IDLH Values [43]

\begin{tabular}{|l|c|}
\hline \multicolumn{1}{|c|}{ Substance } & IDLH Value / ppm \\
\hline Acetaldehyde & 2000 \\
\hline Acrolein & 2 \\
\hline Benzene & 500 \\
\hline Crotonaldehyde & 50 \\
\hline Formaldehyde & 20 \\
\hline Phenol & 250 \\
\hline Toluene & 500 \\
\hline
\end{tabular}

An approximation by Purser [44] shows that an organics concentration of $10 \mathrm{mg} \mathrm{L}^{-1}$ is sufficient to cause incapacitation. For comparison, the $500 \mathrm{ppm}$ IDLH value for benzene corresponds to $1.6 \mathrm{mg} \mathrm{L}^{-1}$.

Polycyclic Aromatic Hydrocarbons (PAH): PAH are human toxicants and environmental pollutants; when agglomerated into combustion-derived particulates they are estimated to kill several million people, globally per year [45]. They originate from various sources including coal coking, diesel emissions, domestic heating, cooking, and from unwanted fires [46]. The molecular weight of PAH strongly influences their distribution between the gas and condensed phases, and is of direct relevance to their toxicity. Those in the low molecular weight category (fewer than four fused rings, e.g. naphthalene, phenanthrene) mainly exist in the gas phase [49]. The tendency to adsorb onto organic carbon (e.g. soot particles) increases with increasing molecular weight so the high molecular weight compounds (more than four fused rings, such as benzo(ghi)perylene, dibenzo(ah)anthracene) occur in the atmosphere mainly as particulates [47].

The Environmental Protection Agency (EPA) have identified and classified 16 priority pollutant PAH. It should be emphasised that it is the chronic toxicity, rather than the acute toxicity, of PAH that is of concern. Some PAHs are recognised carcinogens and mutagens while those not yet classified are considered to be 
potentially harmful. Benzo(a)pyrene (BaP) has been identified as the most toxic PAH species and is used as a reference toxicant for other $\mathrm{PAH}$, although benzo(a)anthracene amongst others are also of great concern $[48,49]$.

In the U.S. it has been reported that cancer accounts for $56 \%$ of line-of-duty deaths amongst fire fighters, [50] around twice the national average. Only recently have these cancers (myelomas, lymphomas, melanomas, leukaemia, prostate, testicular, brain, digestive tract and skin cancers), and the carcinogenicity of the PAH and other compounds identified in fire effluents, been combined to estimate the carcinogenicity of fire effluents $[51,52,53,54]$.

Table 3 lists the 16 major PAHs together with carcinogenic classifications as defined by the International Agency for Research on Cancer (IARC)[55]. IARC classifications are as follows: Group 1 - carcinogenic to humans, Group 2A - probably carcinogenic to humans, Group 2B - possibly carcinogenic to humans, Group 3 - unclassifiable as to carcinogenicity to humans, Group 4 - probably not carcinogenic to humans.

Table 3 . The 16 priority PAHs as defined by the EPA.

\begin{tabular}{|l|c|}
\hline \multicolumn{1}{|c|}{ Name } & Toxicity data \\
\hline Benzo(a)pyrene & IARC Group 1 \\
\hline Dibenzo(ah)anthracene & IARC Group 2A \\
\hline Naphthalene & IARC Group 2B \\
Benz(a)anthracene & \\
Chrysene & \\
Benzo(b)fluoranthene & \\
Benzo(k)fluoranthene & \\
Indeno(1.2.3-dc)pyrene & \\
\hline Acenaphthene & IARC Group 3 \\
Fluorene & \\
Phenanthrene & \\
Anthracene & \\
Fluoranthene & \\
Pyrene & \\
Benzo(ghi)perylene & \\
\hline Acenaphthylene & No IARC classification \\
\hline
\end{tabular}

A large number of PAH structures have been identified in fire effluents, some with greater carcinogenicity than the well-known benzo-a-pyrene $(\mathrm{BaP})$. While relationships have been established to show the links between exposures to $\mathrm{PAH}$ and cancer, and atmospheric particulates $\left(\mathrm{PM}_{2.5}\right)$ and respiratory and cardiovascular diseases (acute lower respiratory illness, cerebrovascular disease, ischaemic heart disease, chronic obstructive pulmonary disease and lung cancer) [56], the specific agents responsible have not been positively identified. The shape, size, and composition of particulates determine their toxicity [57,58]. Organic species are chemisorbed onto their surface through transition metal oxides [59,60,61]. This results in surface-stabilized, environmentally persistent free radicals (EPFR), which continue to exist in ambient air from hours to months, and can last at least $12 \mathrm{~h}$ in biological fluids. In laboratory animals and human lung cell lines they have been shown to cause the increased oxidative stress resulting in regeneration of reactive oxygen species (ROS) in biological systems, and associated with cancer, pulmonary and other diseases $[62,63]$. The formation of potentially toxic particulates, polycyclic aromatic hydrocarbons, and isocyanates, and their distribution between gas phase and solid phase for different building material fires has been investigated [47].

Analysis of VOCs/SVOCs and PAH in a series of experimental house fires where cooking oil or a single sofa were used as initial fuel packages has been reported [64]. The initial fuel packages were either cooking oil or a single sofa; these were burned both alone, and in furnished surroundings. Experiments were also carried out where the fire compartment was furnished. The ventilation conditions were varied between experiments by having the door and/or window to the room open or closed for the duration of the burn. 
Benzo(a)pyrene, the PAH of greatest toxicological concern, was detected in the majority of fires and most frequently in the developing and developed stages of fire. This is a particular concern due to the known mutagenic and carcinogenic effects of this molecule.

Isocyanates: The potent respiratory sensitisers, isocyanates, triggering asthma, and sometimes death after a single exposure, have been identified in fire effluents $[65,66]$. Isocyanates are widely used in the manufacturing of flexible polyurethane (PU) foams for soft furniture and rigid PU foams for insulation in buildings as well as fridges and freezers. Due to their versatility and wide range of applications, isocyanatecontaining products can be found in significant quantities throughout the built environment. The two main products in the isocyanate market, with an approximate market share of $90 \%$, are both di-isocyanates: isomers of toluene-di-isocyanate (TDI) and diphenylmethane-di-isocyanate (MDI). Inhalation of isocyanates is the most important human exposure route and may result in respiratory sensitisation [67]. There is also limited evidence that dermal contact may result in human respiratory sensitisation [68]. The high chemical reactivity of isocyanates is reflected in their toxicity, as exposure to isocyanates is one of the most common causes of occupational asthma in developed countries. Additionally, low concentrations of airborne isocyanates are acutely toxic following inhalation, and the production of isocyanates and products containing isocyanates is therefore heavily regulated from a health and safety at work perspective, particularly polyurethane (PU) based foams, fillers and coatings. However, airborne isocyanates have also been sampled in fire effluent from building materials during the early stages of fire development [65].

Airborne isocyanates from 23 common materials found in buildings were sampled after being generated by a cone calorimeter [69]. The main findings from these initial small scale tests were that all nitrogencontaining materials included in the study produced isocyanates upon thermal degradation. Airborne isocyanates were also sampled from an ISO 9705 room, using a sofa containing flexible PU foam. The experiment went to flashover. The relatively high amounts of isocyanates measured, mainly ICA, but also MIC, PHI and 2,4-TDI, from this test were considered a potential health hazard.

Using the steady state tube furnace (ISO TS 19700), the generation of isocyanates from materials such as PUR mattresses and insulation materials as well as PVC carpets and wood board were analysed [11,47]. A correlation between the magnitude of the obtained yields for isocyanates from the PUR materials from the well-ventilated stage and yields from PUR from the cone calorimeter was reported. Additionally, no significant difference between the yield of isocyanates from the PUR materials burnt at well-ventilated and under-ventilated conditions were observed. Moreover, it was reported that the smaller and more volatile mono-isocyanates were found almost exclusively in the gas phase, whereas the non-volatile MDI never was found in the vapour phase but only in the particle phase of the fire effluent.

Halogenated Dioxins: Polychlorinated dibenzo-p-dioxins (PCDD) and polychlorinated dibenzofurans (PCDFs) are toxic, chemically and thermally stable, and have a tendency for being strongly adsorbed on the surface of particulate matter. The rate of formation of PCDD/Fs is a function of temperature and the quantity of unburnt carbon, which is dictated by the oxygen level $[70,71,72]$. Numerous studies on animals have also confirmed that some dioxin congeners are carcinogenic and produce mutagenic effects in certain species. However, it is difficult to extrapolate data from different fire test methods as there are significant differences in both the combustion conditions (such as large variation in temperature and oxygen environments), and also varying concentrations of precursors and chlorine in the product gases [73]. Therefore, at present, our knowledge of the distribution and quantities of these species in fire gases is fairly limited. General awareness of the fact that fires may present dramatic and persistent adverse effects on the environment has been accentuated by a number of high impact incidents over the past half century [74]. Since quantitative data on environmentally hazardous components of fire effluent cannot be obtained from accidental fires, appropriate data must come from real-scale fire tests and simulations involving small-scale physical fire models. Such data is almost entirely absent from literature reports or enquiries relating to these incidents.

Particulates: Smoke not only impairs escape by visual obscuration, but also contains particulate matter which is sufficiently small to pose a respiratory hazard. In spite of large amounts of particulates generated in a fire, relatively few investigations have been made into their size, distribution and composition from unwanted fires [75]. 
The particle size distribution is dependent on the material, temperature, fire conditions and effluent flow. The particle size of the spherical droplets from smouldering combustion is generally of the order of $1 \mu \mathrm{m}$, while the size of the irregular soot particulates from flaming combustion has a much wider size range. This makes particle size distribution harder to determine and dependent on measuring technique and sampling position. The deposition zones for humans as a function of particle size are presented in Fig. 4.

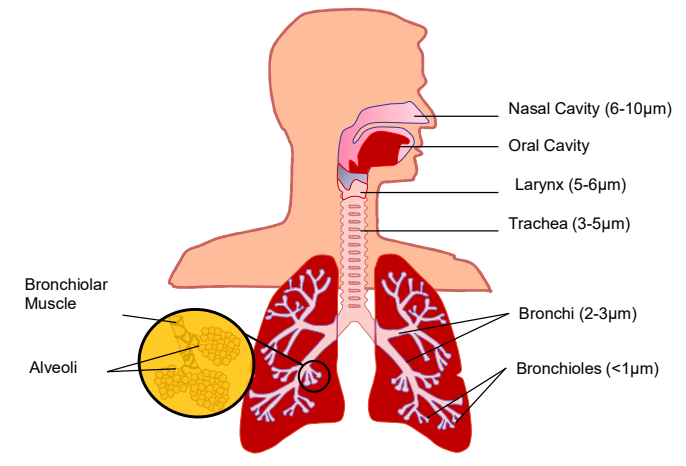

Fig. 4. Deposition zones of particulates in the human respiratory tract [2].

PAH agglomerate into small spherical particles, which then adhere to one another, like a tangled string of beads, eventually forming soot particles, which are large enough to be trapped on a filter. Further, PAH can then be adsorbed onto the growing soot surface. Both the volatile PAH and the soot particles will remain airborne almost indefinitely, but have the potential to cause significant damage to the lungs. Although a large amount of research has focussed on the toxicity of airborne particulates [76], very little work has been reported on particulate emissions from unwanted fires [75]. Different particle size ranges are deposited in different parts of the respiratory tract. $\mathrm{PM}_{2.5} \mathrm{~S}$ (particles with diameter less than $2.5 \mu \mathrm{m}$ ) result in inflammation of the terminal bronchioles can result in their complete blockage. Oedema fluid disrupts the dispersion of the lung surfactant, causing collapse of the alveolae from higher surface tension of the fluid. The smallest particles $(<0.5 \mu \mathrm{m})$, penetrate the lung interstitium (between the alveolar surface and the blood capillaries), where they have been shown to be particularly dangerous, causing interstitial and luminal oedema. They can also cross the air-blood barrier and enter the blood stream, triggering dangerous immune responses from the white blood cells, including polymer fume fever, and increased platelet stickiness, leading to heart attacks. Attempts to characterise pyrogenic particulates, and the toxicants bound to them, are hampered by the establishment of dynamic equilibrium on smoke particles when trapped on a filter.

\section{TOXICITY ASSESSMENT FROM SMALL AND LARGE SCALE TEST METHODS}

Assessment of toxic hazard is increasingly being recognised as an important factor in the assessment of fire hazard. Prediction of toxic fire hazard depends on two parameters.

1. Time-concentration profiles for major products. These depend on the fire growth curve and the yields of toxic products.

2. Toxic potency of the products, based on estimates of doses likely to impair escape efficiency, cause incapacitation, or death.

Some criteria for the assessment of physical fire models have been published in ISO 16312-1 and reviewed elsewhere [29]. Essentially, these require toxic product yields from bench-scale tests to be replicated in large scale fires. For a bench scale method to differentiate between the stages of a fire, it must allow the equivalence ratio and/or the combustion efficiency to be quantified so that the individual fire stages can be identified, and the product yields correlated to each stage.

Most bench-scale methods used for toxicity testing are designed to reproduce a single fire stage or combustion condition, where real-scale fires simultaneously involve different fire stages in different places, which are changing with time. These methods can also be classified as those with constant combustion conditions, often achieving a prolonged steady-state period, and those with non-constant combustion 
conditions. Those with constant combustion conditions are best suited to producing data suitable for comparison and modelling, but only the steady state tube furnace methods, such as ISO TS 19700 (the Purser Furnace) have been specifically designed to achieve this. Most other bench-scale methods have nonconstant combustion conditions, such as those in closed chambers exposed to a constant source of heat, including the toxicity tests derived from the NBS smoke chamber (ISO 5659), and static tube furnace tests, such as the NF X 70-100. Intermediate between these two extremes are those that can produce quasi-steady combustion conditions such as the Cone Calorimeter (ISO 5660-1) with controlled atmosphere attachment, and the Fire Propagation Apparatus (ASTM E 2058). The difficulty of replicating the conditions of fully developed under-ventilated flaming on a bench-scale is caused by two practical problems. In fully developed fires in under-ventilated conditions, the high heat flux is large enough for burning to continue at low oxygen concentrations (e.g. $\sim 5 \%$ ); in bench-scale experiments the heat flux is usually constant, and often insufficient to sustain flaming at such low oxygen concentrations. In fully developed fires, mixing and recirculation of the fire effluent ensures that all the oxygen present passes into the fire plume; in many bench-scale apparatuses, such as the controlled atmosphere cone calorimeter (CACC) or smoke chamber, an unknown quantity of fresh air bypasses the fire plume, so the ventilation condition remains undefined. A schematic of the SSTF is shown in Fig. 5.

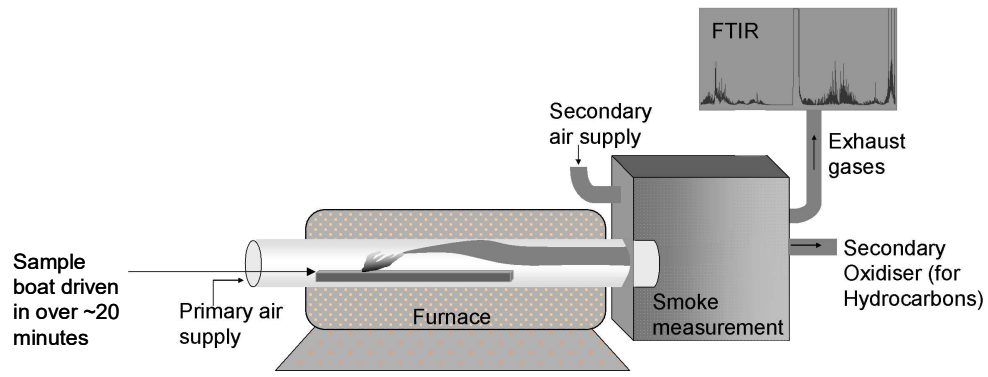

Fig. 5. Steady State Tube Furnace [18].

ISO TS 19700 replicates the full range of fire conditions, characterising the fire behaviour of materials under controlled and well-defined laboratory conditions, in terms of the equivalence ratio $(\phi)$ or more roughly the $\mathrm{CO} 2 / \mathrm{CO}$ ratio in the fire effluent [77]. It was shown that for many common materials, the yield of toxic products such as $\mathrm{CO}, \mathrm{HCN}$, organoirritants, and smoke increases by a factor between 10 and 50 as the fire changes from well-ventilated $(0.5<\phi<0.7)$ to under-ventilated $1<\phi<5)$. The figure shows how the $\mathrm{CO}$ yield (itself a useful marker of incomplete combustion) of most simple polymers and products rises rapidly as $\phi$ increases from 0.5 to 1.5 .

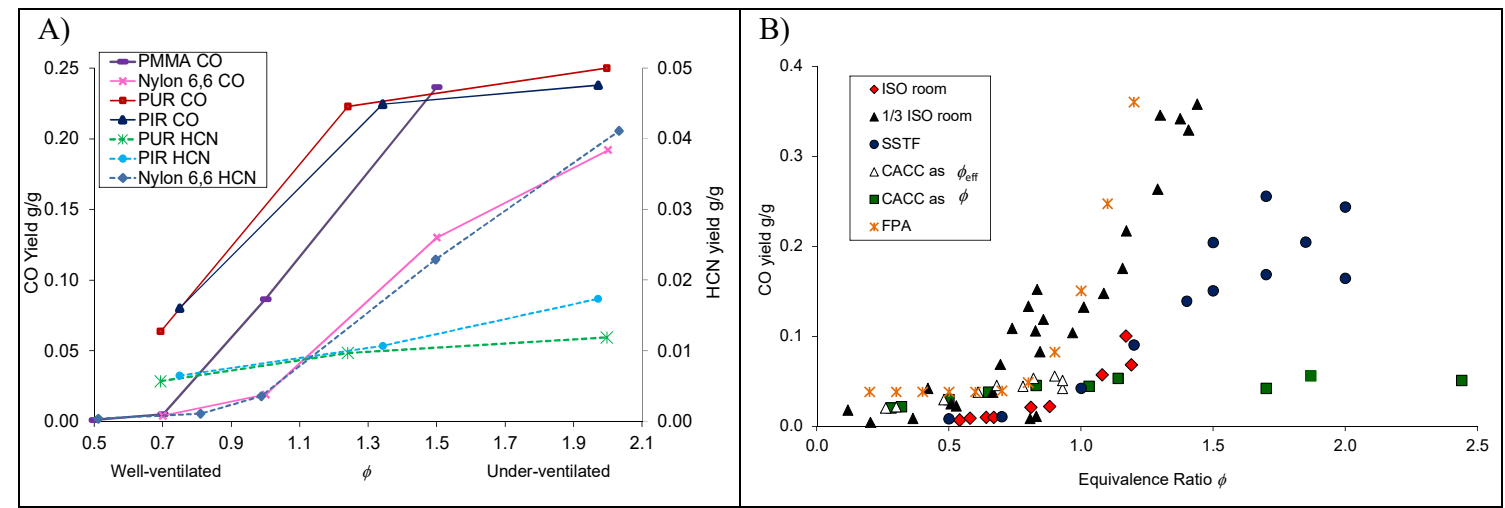

Fig 6. A) Carbon monoxide yields for various polymers and products as a function of equivalence ratio and $\mathrm{B}$ ) Comparison of $\mathrm{CO}$ yield for polyamide 6.6 from steady state tube furnace, controlled atmosphere cone calorimeter, fire propagation apparatus, with ISO Room, and 1/3 ISO Room as a function of equivalence ratio $\phi$. [2] 
Fire effluent toxicity must be determined as a function of the material and of fire conditions, particularly temperature and oxygen availability in the fire zone. The steady state tube furnace, and the fire propagation apparatus show acceptable agreement with large scale data over the range of fire conditions. The controlled atmosphere cone calorimeter and the NBS smoke chamber cannot replicate the high yields of toxic gases (especially CO and $\mathrm{HCN}$ ), which occur in under-ventilated fires. The NF X 70-100 replicates the toxic product yields intermediate between well-ventilated and under-ventilated flaming. Only the SSTF and FPA are engineering tools capable of taking measurements under controlled conditions allowing the relationship between equivalence ratio and the toxic product yields to be investigated in order to provide suitable inputs to engineering based assessment of toxic fire hazard [2,26]. Figure 6B shows a comparison of bench-scale yields with those produced in the ISO 9705 room as a function of $\phi$. The $\phi$ data for the CACC was corrected for the by-pass air that passed through the chamber, without interacting with the flame, as $\phi_{\text {eff. }}$ The analysis has been described in detail elsewhere [28].

\section{Problems with smoke chamber for assessment of fire toxicity}

Unfortunately, the smoke chamber has been adopted by the mass transport industries as regulatory assessment tool for fire toxicity. In the smoke chamber most of the toxic gas production should occur towards the end of the test, when the oxygen is most depleted, provided flaming combustion is maintained. However, it is this stage where it is most difficult to maintain flaming combustion. While the smoke chamber is well-suited to the measurement of visual obscuration, during the early stages of flaming, where the smoke can be quantified non-destructively, and is independent of the smoke layer height and distribution, using the smoke chamber to quantify toxic gas generation presents a number of problems.

The ventilation condition, or equivalence ratio, corresponding to the time when the products are generated is unknown, because an unknown fraction of the available oxygen will be accessible to the fire plume. Indeed, the circulation within the chamber will depend primarily on the heat release rate. When sampling a stratified fire effluent from a fixed point, such as a tube $20 \mathrm{~cm}$ below the chamber roof, this could be too low, so missing the main effluent plume altogether, or sample from its centre, without dilution. The use of a fan, in some variants of the smoke density chamber standard, disrupts the burning process considerably, and results in recirculation of fire effluent through the flame zone. The act of sampling, and clean-up prior to gas analysis, of the fire effluent will change its composition - if the fire gases are sampled in real time, it may be possible to isolate individual fire stages, but then the effluent may change during analysis, or may not be returned to the chamber after analysis. If the analyte is returned to the chamber, it will usually have been filtered removing both the particulates and the gases absorbed onto them, to protect the analysers, while acid gases may have deposited onto the sampling line. Similarly, the high surface area of the chamber wall will promote deposition and disproportionately larger losses of certain analytes, such as hydrogen chloride $(\mathrm{HCl})$ or hydrogen bromide $(\mathrm{HBr})$. However, of greatest significance in quantification of the toxicity of fire effluents is that the most important under-ventilated conditions cannot be replicated [28].

\section{FIRE RETARDANTS}

Gas phase action: The widespread use of synthetic polymers in Europe and the U.S. led to an increase in fires and fire fatalities. In the 1970s halogenated flame retardants started to be used to make products less flammable. While halogen-based fire retardants are very effective in reducing fire risk, i.e., the probability of occurrence of a fire, they show a high fire hazard, that is, the probability of producing toxic, corrosive, obscuring smokes or when involved in a developed fire, and the fire is too big to be extinguished. Halogenated flame retardants act by releasing hydrogen bromide $(\mathrm{HBr})$ or hydrogen chloride $(\mathrm{HCl})$ which interferes with the gas phase free radical reactions, typically producing more carbon monoxide, smoke and other products of incomplete combustion [78]. The dense smoke obscures escape routes and contaminates property, while the resultant halogen acids are highly corrosive - significantly increasing the costs of unwanted fires. The threat to people, structures, and goods involved in the fire may discourage the use of these fire retardants, despite their versatility and ease of incorporation.

Gas phase flame retardants, such as those based on organohalogen or organophosphorus compounds, interfere with the free radical reactions responsible for flaming combustion. This results in incomplete oxidation of vapour phase fuel molecules, leading to higher yields of all products of incomplete combustion. 
These are all more toxic than the cleaner products of complete combustion (carbon dioxide and water), and include carbon monoxide, hydrogen cyanide, hydrocarbons, oxygenated organics (including organoirritants, such as acrolein and formaldehyde) and larger cyclic molecules such as polycyclic aromatic hydrocarbons and soot particulates. Fire toxicity increases as combustion becomes more incomplete, which can arise from chemical quenching (for example by gas phase flame retardants), insufficient heat (for example during smouldering), or when the fire becomes ventilation controlled, and there is insufficient oxygen for complete combustion $[15,77]$.

Thus in a fire, gas phase flame retardants will act to increase the gas phase products of incomplete combustion, and hence the yields of toxic gases and smoke, when compared to either the non-flame retarded polymer, or the same polymer incorporating a condensed phase fire retardant, which increases the char yield. As most fire deaths, and most fire injuries result from toxic gas inhalation, the use of gas phase flame retardants is a compromise, between supressing ignition and increasing the fire toxicity (or decreasing the fire risk at the expense of increasing the fire hazard). Recently it has been shown that the phosphorus flame retardants which act in the gas phase have a smaller influence on $\mathrm{CO}$ and $\mathrm{HCN}$ yields than the corresponding brominated flame retardants in industry standard formulations of PA 6.6 meeting UL $94 \mathrm{~V}-0$ at $0.8 \mathrm{~mm}$ [2].

Halogenated flame retardants tend to be non-specific in their action, so one flame retardant can be incorporated into many polymers. This has increased their popularity amongst plastic compounders and product manufacturers, who do not have the expertise to develop such formulations. The ease of incorporation of halogenated FRs is matched by their ease of release, particularly at elevated temperatures, such as in televisions and other electronics, or during breakdown of the polymer, during use, or at end-oflife, and leaching (especially in foam or textile products), allowing significant quantities to escape into the environment. In addition, losses of brominated flame retardants have been reported during manufacture and end-of-life processing.

Many halogenated flame retardants are persistent and bioaccumulative, and are now ubiquitous throughout the built and natural environment [79,80]. In 2010 a group of over 100 eminent environmental scientists signed the San Antonio statement on halogenated flame retardants [81] condemning their continued use and requesting urgent remedial action. These persistent organic pollutants (POPs) take several years to break down in the environment, are bioaccumulative (they accumulate in plants and animals, becoming more concentrated as they move up the food chain), and are toxic. All of the 30 chemicals currently designated as POPs by the Stockholm Convention are organohalogen compounds [82]. Studies have shown higher levels of halogenated flame retardants in house dust in California and the UK, where the most stringent furniture flammability regulations operate [83]; at lower levels they have been detected in flora and fauna, from the developed world to the pristine Himalayan and Arctic regions. Very high levels have been detected in the Pearl River delta in southern China, where many electronic recycling activities are based. The most detailed studies of health effects have concentrated on polybromodiphenyl ethers (PBDEs), proven endocrine disruptors in both experimental animals and humans. Elevated levels have been found in human blood serum in Californian children at 5 times the US average, and 10-100 times the European and Mexican average. These elevated levels have been linked to infertility, and hyperactivity and attention disorders in children etc [84]. This has put a lot of pressure on the fire retardant community to develop "halogen-free" fire retardants, because that is what product manufacturers are demanding.

Condensed Phase Action: In contrast, modern fire retardants reduce fuel release to the gas phase, often by formation of a protective barrier layer, which acts as a radiation shield, and inhibits the flow of fuel and oxygen [85]. Barriers can be formed or reinforced with inorganic nanoparticles, such as montmorillonite [86]. The barrier is often carbonaceous, and increasing the char yield is synonymous with reducing the flammability. Moreover, but reducing the volatile evolution, the amount of toxic effluent is reduced, and for a given ventilation rate, the ventilation condition becomes more well-ventilated, also reducing the toxicity. Char formation has been enhanced in polyethylene, using functionalised graphene oxide [87]; in PMMA using graphene oxide and a nickel-aluminium layered double hydroxide [88]; in ABS copolymer, with graphene nanosheets combined with a metal hydroxide [89]; in polyamide 6 using graphene supported cobalt oxide and nickel oxide [90]; and in epoxy resins using silica, attached to cobalt-aluminium layered double hydroxide spheres [91]. Enhancement of the barriers can be achieved in intumescent systems, where 
gas is released within the molten polymer, causing significant swelling, and so increasing the effectiveness of the thermal barrier [92], for example in polyethylene [93], polypropylene [94] and polystyrene [95]. Carbon nanotubes (CNT) have also been used as potential fire retardant additives, given their similarity to carbonaceous char, with mixed success [96]. This study also found that in the SSTF polypropylene samples with intumescent fire retardant and/or CNTs, or both, produced much more CO compared to the pure polymer during all fire stages, and hydrocarbon yield from the pure polymer increased more with the equivalence ratio, indicating that CNTs promote the formation of smoke particulates from hydrocarbons. However, questions have also been raised about their long term safety, and whether airborne nanotubes (of similar dimensions to asbestos particles) could be equally hazardous [97].

There have been other reports of the effect of fire retardants on fire toxicity, such as the use of hollow mesoporous silica, attached to a cobalt-aluminium layered double hydroxide, itself attached to graphene, in order to reduce the fire toxicity of epoxy resins [98], where it was found that the amount of CO and volatile organic compounds from the epoxy resin decomposition were significantly suppressed. Cerium-doped manganese oxide-graphene hybrid sheets were also found to suppress the amount of organic volatiles and $\mathrm{CO}$ during decomposition epoxy resins [99]. Less success was obtained on incorporating a new phosphorous- and nitrogen-containing reactive monomer to form a polystyrene copolymer [100]. The results obtained from the SSTF indicated that the carbon monoxide and smoke yield density were increased due to the incomplete combustion of the copolymer.

\section{Fire Retardancy and Performance in large scale fires}

The effect of fire retardants on large scale fire behaviour is less clear. Fire retardants can delay ignition, or reduce heat release rate in small-scale tests, and are most effective in the "first object ignited". However, they are only effective on a larger scale if they decrease the radiant component of heat transfer. Radiant heat allows the flames to spread horizontally or even downwards. Soot particles absorb heat from the flame, and emit infrared radiation in all directions, which can heat adjacent objects causing flame spread, and is ultimately responsible for the devastating impact of unwanted fires. Gas phase free radical inhibitors, such as halogenated flame retardants, which act by interfering with the combustion process increase the soot yields and hence the severity of a large scale fire, as soot particles convert more heat in flames into radiation, spreading the fire to other objects, alongside and below the flames [101]

The fire toxicity of large scale fire tests has been investigated, and demonstrated good correlations with the results from the SSTF $[28,102]$. Other large scale fires have been investigated for their toxicity, showing life-threatening conditions in an entire house when a single sofa was burning [ ${ }^{103}$ ] and identifying the presence of significant quanties of trichoropropyl phosphate flame retardants in the residues of another fire involving a single sofa in a domestic property [64].

\section{CONCLUSIONS}

Fire effluent toxicity is the largest killer, and greatest cause of injury in fires. Assessment of fire gas toxicity is an essential component of fire hazard analysis. The hazard generally changes with fire scenario, and the toxic product yields are lower in well-ventilated flaming fires (at least with non-halogen containing materials). $\mathrm{CO}$ is generally considered to be the most toxicologically significant component in fire gases. However, because of the ease of measurement of $\mathrm{CO}$ compared to other toxicants (particularly $\mathrm{HCN}$ ) in fire victims, it has been suggested that CO may not be the only significant toxic fire gas. Laboratory results show the much greater toxicological significance of $\mathrm{HCl}$ from PVC, and $\mathrm{HCN}$ from PA 6.6 in underventilated conditions. The relative toxicities show variation of up to two orders of magnitude with change in fire scenario while the individual polymers show different trends with respect to change in fire condition. For the purposes of fire hazard assessment, fire toxicity must be determined as a function of both the material and of fire conditions, particularly temperature and oxygen availability in the fire zone. The steady state tube furnace is both a standard test method and a research tool that can provide building engineers and designers with valuable data related to fire hazard. The significant advantage of the apparatus over other techniques is its capability to replicate the whole range of fire conditions. The steady state tube furnace, and the fire propagation apparatus show acceptable agreement with large scale data over the range of fire conditions. The controlled atmosphere cone calorimeter and the smoke density chamber fail to replicate the 
high yields of asphyxiant gases, $\mathrm{CO}$ and $\mathrm{HCN}$, which occur in under-ventilated fires. This shows that they are unsuitable for assessment of toxic hazard of fire effluents. The non-dynamic tube furnace replicates the toxic product yields intermediate between well-ventilated and under-ventilated flaming, seemingly independent of the pyrolysis temperature. Only the SSTF and FPA are capable of generating data under controlled conditions, allowing the relationship between equivalence ratio and the toxic product yields to be quantified, in order to provide suitable inputs to engineering based assessment of toxic fire hazard.

The adoption of the smoke density chamber (ISO 5659-2) to quantify fire toxicity in international shipping [104] and across European rail network [105] is of great concern. The rejection by ISO of the smoke density chamber as a toxicity test (DIS 21489) due to its irreproducibility ignores the more serious issue. The apparent inability of the smoke density chamber to replicate under-ventilated flaming renders it unsuitable for the assessment of fire effluent toxicity. Typically, in well-ventilated flaming there would be 0.02 grams of carbon dioxide per gram of burning polymer and 0.002 grams of hydrogen cyanide per gram of nitrogen containing polymer while in under-ventilated flaming there would be typical yields of $0.2 \mathrm{~g} / \mathrm{g}$ of $\mathrm{CO}$ and $0.06 \mathrm{~g} / \mathrm{g}$ of HCN: increases by factors of 10 and 30 .

\section{FUTURE CHALLENGES}

\section{Assessment of Acute Toxicity}

Fire effluents contain such rich cocktails of asphyxiants, irritant gases and vapours, and particulates that full characterisation has never been undertaken. Only acute toxicity in well-ventilated conditions is assessed for materials used in mass transport applications; for performance based engineering (PBE) assessments ISO stipulate that the concentrations of eight acute toxic gases $\left(\mathrm{CO}, \mathrm{CO}_{2}, \mathrm{NO}, \mathrm{NO}_{2}, \mathrm{SO}_{2}, \mathrm{HCN}, \mathrm{HBr}\right.$ and $\left.\mathrm{HCl}\right)$ should be quantified, and related to rat lethality data, or estimates of human incapacitation. In the ISO assessment of fire toxicity, no account need be taken of organic irritants ("unless their presence is known or suspected"), while particulate matter, or chronic toxicants or carcinogens are not quantified at all. With the development of highly sensitive, lower cost instrumentation, a more complete assessment of fire effluent toxicity can be achieved, providing a complete set of data for a fire safety assessment. It is no longer acceptable that building occupants who are trapped by a fire should then be exposed to carcinogens during their escape, or while they wait to be rescued.

\section{Input to Fire Safety Engineering}

The necessary, rapid shift to lightweight, insulating, construction products poses a serious threat to fire safety, because of their combustibility. The problem is made worse because the products have been designed to demonstrate non-combustibility in fire tests, (e.g. by covering with gypsum board) yet in real fires they burn and release toxic effluent. Moreover, some materials are very flammable, while others, such as wood, burn slowly, and many others not at all. The toxic hazard will depend on both the toxic product yield and the mass loss or burning rate. Fire safety engineers (FSE) need to demonstrate that occupants can all escape safely before a fire develops.

European and National requirements for reduction of carbon emissions specify better insulation of all homes. Existing buildings may be clad in insulation materials while new buildings are likely to use novel construction methods and materials, with combustible insulation products replacing non-combustible walls and ceilings. In comparison to traditional materials, many insulation materials such as expanded polystyrene (EPS) foam, and polyurethane (PUR) or polyisocyanurate (PIR) foam, present a greater fire hazard, resulting in quicker ignition and rapid flame spread, being more combustible, less effective as fire barriers, and having much higher fire toxicity. A detailed study on six insulation materials shows very large differences in fire toxicity, ranging from very low for non-combustible mineral wool (MW) insulation, to intermediate toxicity for EPS, to very toxic for PUR and PIR foams [106]. As a direct result of this work, and communication with the European Commission and EU Parliament, DG GROW have commissioned a study on the need to regulate the smoke toxicity of construction products [107]. The increased use of lightweight insulation materials will help to meet targets for carbon emissions, but could create a time-bomb in terms of fire safety - with many homes being inherently flammable before the extent of the problem is fully recognised. Three recent examples stand out: the Colectiv Nightclub fire in Bucharest in Oct 2015, where most of the 64 
people died as a result of inhaling HCN from burning polyurethane foam [108]; the fire at the Cuba Libre Club in Rouen where 13 people died from smoke inhalation from burning EPS in Aug 2016 [109]; and the fire in Fort McMurray, Canada, in May 2016, which destroyed 2400 homes and buildings (costing \$4.5 bn) and lasting over 2 months, and providing an early warning of problems in the future.

A simplified methodology has recently been proposed [110] for combining the extent of burning (quantified using the results of the European SBI test, EN13823, required for all construction products, so all the data is publically available) with toxic product yields (measured using the steady state tube furnace) allowing a quick assessment of the mass of material which would produce a lethal atmosphere in a given volume. Although the approach is simplistic, it provides FSE with a tool for estimating fire toxicity in a building. This challenging work needs to be extended and validated using a series of full-scale fire tests to quantify the contribution of different types of construction products.

\section{Atmospheric and Particulate Toxicity}

Almost all air pollution continues to be caused by combustion processes. In most cases combustion efficiency is key to limiting pollutant emissions: although vastly more fuel is burned in controlled conditions, unwanted fires contribute $10 \%$ overall PAH and particulates, because of their much lower combustion efficiency [11]. In both cases robust analysis of combustion products is the key to assessing their hazards. Combustion derived particulates have been attributed to 3 million deaths per year across the globe, mostly from open cooking and heating within homes in India and China [111]. Since the particulates are composed of agglomerated PAH and hydroxy-PAH, with other toxicants adsorbed onto them, and possibly carrying EPFRs, the major challenge is to characterise pyrogenic particulates.

Across Europe, large waste storage sites are increasingly igniting and burning for long periods. In the UK, 300 of the 400 large fires each year occur at waste facilities, including a waste carpet dump burning for over 18 months, often blowing smoke of unknown toxicity into people's homes. Facilities are only being developed for monitoring such incidents, but they are clearly major sources of toxic emissions. Large waste fires have already included tyres, furniture, plastic and recyclate, cables, white goods (fridges and washing machines etc.) and carpets. Wildland fires are a growing European problem and a significant number of deaths have been recorded as a result of the fire toxicity of wildland fires. In the heatwave in Moscow in 2010, with an estimated death toll of 56000 , average $\mathrm{PM}_{10}$ levels exceeded $300 \mu \mathrm{g} / \mathrm{m}^{3}$ on several days, resulting in an 11000 excess of deaths from cardiovascular, respiratory, genitourinary and nervous system diseases, with the combination of high temperatures and air pollution contributing to a further 2000 deaths [112].

\section{REFERENCES}

[1] Fire statistics monitor: April 2015 to March 2016, UK Government, Home Office, https://www.gov.uk/government/statistics/fire-statistics-monitor-april-2015-to-march-2016 and preceding editions.

[2] Stec, A.A. and Hull, T.R., Fire Toxicity, Woodhead Publishing, Cambridge. 2008 https://doi.org/10.1533/9781845698072.1

[3] Molyneux, S., Hull, T.R., Stec, A.A. (2014) The Effect of Gas Phase Flame Retardants on Fire Effluent Toxicity, Polymer Degradation and Stability 106:36-46. https://doi.org/10.1016/j.polymdegradstab.2013.09.013

[4] Stull, J.O. (2008) U.S. Fire Administration Firefighter Autopsy Protocol, Federal Emergency Management Agency.

[5] Fire Statistics in the Russian Federation, The Ministry of the Russian Federation for Civil Defence, Emergencies and Elimination of Consequences of Natural Disasters (EMERCOM of Russia), http://www.en.mchs.ru/stats/Fire Statistics in the Russian Federatio, 2017.

[6] Polish Fire statistics, 2014 http://www.straz.gov.pl/page/index.php?str=2379, 2014.

[7] International Association of Fire and Rescue Service (CTIF), world fire statistics, http://www.ctif.org/ctif/world-fire-statistics, 2017. 
[8] Stec, A.A., Giebultowicz, J., Rużycka, M., Wroczynski, P., Purser, D.A., (2017) Analysis of Fire Deaths in Poland and Influence of Smoke Toxicity, Forensic Science International, In Press

[9] Air Quality in Europe - 2016 Report, European Environmental Agency, 2016 http://www.eea.europa.eu/publications/air-quality-in-europe-2016

[10] Persson, P., Simonson, M., (1998) Fire Emissions Into the Atmosphere, Fire Technology, 34:26627. https://doi.org/10.1023/A:1015350024118.

[11] Blomqvist, P., Persson, B., Simonson M., (2007), Fire Emissions of Organics Into the Atmosphere, Fire Technology 43:213-231 https://doi.org/10.1007/s10694-007-0011-y.

[12] Defra National Statistics Release: Emissions of air pollutants in the UK, 1970 to 2015, UK Government, https://www.gov.uk/government/statistics/emissions-of-air-pollutants

[13] Avagyan, R., Nyström, R., Lindgren, R., Boman, C., Westerholm, R., (2016) Particulate HydroxyPAH Emissions From a Residential Wood log Stove Using Different Fuels and Burning Conditions, Atmospheric Environment, 140:1-9. http://dx.doi.org/10.1016/j.atmosenv.2016.05.041

[14] Hull T.R., Quinn R.E., Areri I.G. and Purser D.A., (2002) Combustion Toxicity of Fire Retarded EVA, Polymer Degradation and Stability 77:235-242 https://doi.org/10.1016/s01413910(02)00039-3

[15] Hull, T.R., Stec, A.A., Lebek, K., and Price, D., (2007) Factors Affecting the Combustion toxicity of Polymeric Materials, Polymer Degradation and Stability, 92:2239-2246. https://doi.org/10.1016/j.polymdegradstab.2007.03.032

[16] Paul, K.T., Hull, T.R., Lebek, K., Stec, A.A., Fire smoke toxicity: The Effect of Nitrogen Oxides, Fire Safety Journal, 43, 243-251, 2008.

[17] Rhodes, J., Smith, C., Stec, A.A., (2010) Characterisation of Soot Particulates From Fire Retarded and Nanocomposite Materials, and Their Toxicological Impact, Polymer Degradation and Stability, 96(3):277-284, doi:10.1016/j.polymdegradstab.2010.07.002.

[18] Stec, A.A., Rhodes, J., (2010) Smoke and Hydrocarbon Yields From Fire Retarded Polymer Nanocomposites, Polymer Degradation and Stability, 96(3):295-300, doi:10.1016/j.polymdegradstab.2010.03.032.

[19] Stec, A.A., Fadell, P., Blomqvist, P., Bustamante-Valencia, L., Sargoza, L. and Guillaume, E. (2011) Quantification of fire gases by FTIR: Experimental characterisation of calibration systems, Fire Safety Journal 46:225-233. https://doi.org/10.1016/j.firesaf.2011.02.004

[20] Stec, A. A., Hull, T. R., Fire Toxicity and its Assessment, Chapter 17 p 453-477, in C A Wilkie and A Morgan (Editors) Fire Retardancy of Polymeric Materials, 2nd Edition, CRC Press Boco Raton (2009).

[21] Hull, T.R., Stec, A.A. Chapter 5: Generation, sampling and quantification of toxic combustion products, (2016) Issues in Toxicology, 2016 (23), pp. 108-138. Royal Society of Chemistry, DOI: 10.1039/9781849737487-00108

[22] Lebek, K., Hull .R., Price, D., Products of Burning Rigid PVC Burning Under Different Fire Conditions, Fire and Polymers: Materials and Concepts for Hazard Prevention, ACS Symposium Series No.922, p334-347, Oxford University Press, (2005).

[23] Stec, A.A., Hull, T.R., Lebek, K., (2008) Characterisation of the Steady State Tube Furnace, Polymer Degradation and Stability, 93:2058-2065. https://doi.org/10.1016/j.polymdegradstab.2008.02.020

[24] Stec, A.A., Hull, T.R., Purser, J.A., Blomqvist, P., Lebek, K., (2008) A Comparison of Toxic Product Yields Obtained From Five Laboratories Using the Steady State Tube Furnace (ISO TS 19700), Fire Safety Science, 9:653-663. https://doi.org/10.3801/IAFSS.FSS.9-653

[25] Purser, J.A., Purser, D.A., Stec, A.A., Moffatt, C., Hull, T.R., Su, J.Z., Bijloos, M., Blomqvist, P., (2013) Repeatability and Reproducibility of the ISO/TS 19700 Steady State Tube Furnace, Fire Safety Journal, 55: 22-34. https://doi.org/10.1016/j.firesaf.2012.10.002

[26] Stec, A.A., Hull, T.R., Lebek, K., Purser J.A., Purser, D.A., (2008) The Effect of Ventilation Condition on the Toxic Product Yields from Burning Polymers, Fire and Materials, 32:49-60, https://doi.org/10.1002/fam.955.

[27] Stec, A.A., Hull, T.R., Purser, D.A. (2009) Comparison of Toxic Product Yields from Bench-Scale to ISO Room, Fire Safety Journal, 44:62-70, https://doi.org/10.1016/j.firesaf.2008.03.005. 
[28] Stec, A.A., Hull, T.R., Purser, D.A., Purser, J.A., Fire toxicity assessment: Comparison of asphyxiant yields from laboratory and large scale flaming fires, (2014) Fire Safety Science, 11, pp. 404-418. DOI: 10.3801/IAFSS.FSS.11-404

[29] Hull, T. R., Paul, K.T., (2007) Bench-Scale Assessment of Combustion Toxicity - A Critical Analysis of Current Protocols, Fire Safety Journal, 42:340-365. https://doi.org/10.1016/j.firesaf.2006.12.006

[30] ISO TS 19706:2004, Guidelines for assessing the fire threat to people. https://doi.org/10.3403/30230674 https://doi.org/10.3403/30150939u

[31] Pitts, W.M. (1995) Global Equivalence Ratio Concept and the Prediction of Carbon Monoxide Formation in Enclosure Fires, Progress in Energy and Combustion Science, 21:197-237 https://doi.org/10.1016/0360-1285(95)00004-2

[32] Hull, T.R., Carman, J.M. and Purser D.A. (2000) Prediction of CO evolution from small-scale polymer fires, Polymer International 49:1259 https://doi.org/10.1002/10970126(200010)49:10<1259::aid-pi573>3.3.co;2-4

[33] Purser, D.A. (2000) Toxic Product Yields and Hazard Assessment for Fully Enclosed Design Fires, Polymer International 49:1232-1255 https://doi.org/10.1002/10970126(200010)49:10\%3C1232::aid-pi543\%3E3.3.co;2-k

[34] Molyneux, S.A., Stec, A.A., Hull, T.R., (2014) The correlation between carbon monoxide and hydrogen cyanide in fire effluents of flame retarded polymers, Fire Safety Science, 11:389-403. 10.3801/IAFSS.FSS.11-389

[35] ISO 13344:2015 Estimation of lethal toxic potency of fire effluents. https://doi.org/10.3403/30097973

[36] Tsuchiya, Y. and Sumi, K. (1972) Evaluation of the toxicity of combustion products, Journal of Fire and Flammability, 3:46-50.

[37] ISO 13571:2012 Life-threatening components of fire - Guidelines for the estimation of time to compromised tenability in fires, ISO, Geneva.

[38] Blomqvist P. Emissions from Fires. Ph. D thesis, Lund University; 2005.

[39] Purser, D.A and Wolley, W.D (1983) Biological studies of combustion atmospheres, Journal Fire Science, 1:118-114. https://doi.org/10.1177/073490418300100204

[40] Wolley, W.D. and Fardell, P.J. (1982) Basic aspects of combustion toxiciology, Fire Safety Journal, 5:29-48 https://doi.org/10.1016/0379-7112(82)90005-4

[41] Purser, D.A. and Buckley, P. (1983) Lung irritation and inflammation during and after exposure to thermal decomposition products from polymeric materials, Medicine Science and the Law, Vol. 23:142-150.

[42] D.A. Purser, unpublished data, 1984.

[43] Documentation for Immediately Dangerous to Life or Health Concentrations (IDLH): NIOSH Chemical Listing and Documentation of Revised IDLH Values (as of 3/1/95), NTIS Publication No. PB-94-195047, U.S. Department of Health and Human Services, Public Health Service, Centers for Disease Control, National Institute for Occupational Safety and Health, Cinncinati, Ohio, USA. https://doi.org/10.1016/b0-12-369400-0/01054-1

[44] Purser, D.A., Assessment of hazards to occupants from smoke, toxic gases, and heat, (2016), SFPE Handbook of Fire Protection Engineering, Fifth Edition, pp. 2308-2428. DOI: 10.1007/978-1-49392565-0_63

[45] World Health Organization, Burden of disease from ambient and household air pollution, 2016: http://www.who.int/phe/health topics/outdoorair/databases/en/ (Accessed 04/12/16).

[46] Blomqvist P, Simonson McNamee M, Andersson P, Lönnermark A. (2011) Polycyclic Aromatic Hydrocarbons (PAHs) Quantified in Large-Scale Fire Experiments Fire Technology, 48:513-528. https://doi.org/10.1007/s10694-011-0242-9

[47] Stec A.A., Readman J.E., Blomqvist P., Gylestam D., Karlsson D., Wojtalewicz D., Dlugogorski B.Z. (2013) Analysis of toxic effluents released from PVC carpet under different fire conditions, Chemosphere; 90:65-71 https://doi.org/10.1016/j.chemosphere.2012.07.037 
[48] Simonson-McNamee M., Tullin C., Stripple H. (2002) Fire-LCA study of TV sets with V0 and HB enclosure material, Chemosphere, 46:737-744. https://doi.org/10.1016/s0045-6535(01)00238-7

[49] Kim K.H., Jahan S.A., Kabir E., Brown R.J. (2013) A review of airborne polycyclic aromatic hydrocarbons (PAHs) and their human health effects, Environment International, 60:71-80. https://doi.org/10.1016/j.envint.2013.07.019

[50] Daniels, R.D., Kubale, T.L., Yiin, J. H., Dahm, M.M., Hales, T.R., Baris, D., Zahm, S.H., Beaumont, J.J, Waters, K.M. and Pinkerton, L.E., (2014) Mortality and cancer incidence in a pooled cohort of US firefighters from San Francisco, Chicago and Philadelphia (1950-2009), Occupational and Environmental Medicine 71:388-397 https://doi.org/10.1136/oemed-2013-101662

[51] Golden, A.L., Markowitz, S.B. and Landrigan, P.J. (1995) The risk of cancer in firefighters, Occupational Medicine 10(4):803-820.

[52] Ide, C.W. (2014) Cancer incidence and mortality in serving whole-time Scottish firefighters 19842005, Occupational Medicine London, 64(6):421-427 https://doi.org/10.1093/occmed/kqu080

[53] Pukkala, E., Martinsen, J.I., Weiderpass, E., Kjaerheim, K., Lynge, E., Tryggvadottir, L., Sparén, P. and Demers, P.A. (2014) Cancer incidence among firefighters: 45 years of follow-up in five Nordic countries, Occupational Environmental Medicine, 71(6):398-404 https://doi.org/10.1136/oemed$\underline{\text { 2013-101803 }}$

[54] Boffetta, P., Jourenkova, N. and Gustavsson, P. (1997) Cancer risk from occupational and environmental exposure to polycyclic aromatic hydrocarbons, Cancer Causes Control, 3:444-472.

[55] International Agency for Research on Cancer, Agents Classified by the IARC Monographs, Volume 1-115, 2016 http://monographs.iarc.fr/ENG/Classification/latest_classif.php

[56] Burnett, R.T., Pope, C.A. 3rd, Ezzati , M., Olives, C., Lim, S.S., Mehta, S, Shin, H.H., Singh, G., Hubbell, B., Brauer, M., Anderson, H.R., Smith, K.R., Balmes, J.R., Bruce, N.G., Kan, H., Laden, F., Prüss-Ustün, A., Turner, M.C., Gapstur, S.M., Diver, W. R. and Cohen, A. (2014) An integrated risk function for estimating the global burden of disease attributable to ambient fine particulate matter exposure, Environmental Health Perspective122:397-403 https://doi.org/10.1289/ehp.122$\underline{\mathrm{a} 235}$

[57] Valavanidis, A., Fiotakis, K. and Vlachogianni, T. (2008) Airborne particulate matter and human health: toxicological assessment and importance of size and composition of particles for oxidative damage and carcinogenic mechanisms, Journal of Environmental Science and Health 26(4):339362 https://doi.org/10.1080/10590500802494538

[58] Franck, U., Herbarth, O., Roder, S., Schlink, U., Borte, M., Diez, U., Kramer, U. and Lehmann, I. (2011) Respiratory effects of indoor particles in young children are size dependent, Science of the Total Environment 409(9): 1621-1631. https://doi.org/10.1016/j.scitotenv.2011.01.001

[59] Dellinger, B., Pryor, W.A., Cueto, R., Squadrito, G.L., Hegde, V and Deutsch, W.A. (2001) Role of free radicals in the toxicity of airborne fine particulate matter, Chemical research in Toxiciology, 14(10):1371-7 https://doi.org/10.1021/tx010050x

[60] Lomnicki, S., Truong, H., Vejerano, E. and Dellinger, B. (2008) Copper Oxide-Based Model of Persistent Free Radical Formation on Combustion-Derived Particulate Matter, Environmental Science and Technology 42(13):4982-4988. https://doi.org/10.1021/es071708h

[61] Dugas, T.R., Lomnicki, S., Cormier, S.A., Dellinger, B. and Reams, M. (2016) Addressing Emerging Risks: Scientific and Regulatory Challenges Associated with Environmentally Persistent Free Radicals, International Journal of Environmental Research and Public Health 8;13(6):573 https://doi.org/10.1021/es071708h

[62] Thevenot, P.T., Saravia, J., Jin, N., Giaimo, J.D., Chustz, R.E., Mahne, S., Kelley, M.A., Hebert, V.Y., Dellinger, B., Dugas, T.R., Demayo, F.J. and Cormier, S.A. (2013) Radical-containing PM0.2 initiates epithelial-to-mesenchymal transitions in airway epithelial cells, The American Journal of Respiratory Cell and Molecular Biology 48(2):188-197 https://doi.org/10.1165/rcmb.2012-0052oc

[63] Balakrishna, S., Saravia, J., Thevenot, P., Ahlert, T., Lominiki, S., Dellinger, B. and Cormier, S.A. (2011) Environmentally persistent free radicals induce airway hyperresponsiveness in neonatal rat lungs. Particle and Fibre Toxicology 8:11. https://doi.org/10.1186/1743-8977-8-11 
[64] Hewitt, F., Christou, A., Dickens, K., Walker, R., Stec, A.A., Release of volatile and semi-volatile toxicants during house fires, (2017) Chemosphere, 173:580-593.

https://doi.org/10.1016/j.chemosphere.2016.12.079

[65] Blomqvist, P., Hertzberg, T., Dalene, M. and Skarping, G. (2003) Isocyanates, aminoisocyanates and amines from fires-A screening of common materials found in buildings, Fire and Materials 27:275-294 https://doi.org/10.1002/fam.836

[66] Bengtström, L., Salden, M., and Stec, A. A., (2016) The Role of Isocyanates In Fire Toxicity, Fire Science Reviews, 5:4. https://doi.org/10.1186/s40038-016-0013-2

[67] Kimber, I., Dearman, R.J., Chemical respiratory allergy: role of IgE antibody and relevance of route of exposure (2002), Toxicology 181-182:311-315. http://dx.doi.org/10.1016/S0300483X(02)00299-8

[68] Pronk, A., (2006) Dermal, inhalation, and internal exposure to 1,6-HDI and its oligomers in car body repair shop workers and industrial spray painters, Occupational and Environmental Medicine, 63(9):624-631, http://dx.doi.org/10.1136/oem.2005.023226

[69] Hertzberg T, Blomqvist P, Dalene M, Skarping G (2003) SP Report 2003:5 Particles and isocyanates from fires Brandforsk project 324-021, SP Swedish National Testing and Research Institute, Borås, Sweden.

[70] Altarawneh, M., Dlugogorski, B.Z., Kennedy, E.M., Mackie, J.C. (2009) Mechanisms for formation, chlorination, dechlorination and destruction of polychlorinated dibenzo-p-dioxins and dibenzofurans (PCDD/Fs) Progress in Energy and Combustion Science, 35(3):245-274 https://doi.org/10.1016/j.pecs.2008.12.001

[71] Tame, N.W., Dlugogorski, B.Z., Kennedy. E.M., (2007) Formation of dioxins and furans during combustion of treated wood, Progress in Energy and Combustion Science, 33(4):384-408. https://doi.org/10.1016/j.pecs.2007.01.001

[72] Huang, H. and Buekens, A. (1995) On the mechanisms of dioxin formation in combustion process, Chemosphere 31:4099-4117 https://doi.org/10.1016/0045-6535(95)80011-9

[73] Blomqvist, P., Rosell, L. and Simonson, M. (2004) Emissions from fires part II: Simulated room fires, Fire Technology 40:59-73 https://doi.org/10.1023/b:fire.0000003316.63475.16

[74] ISO 26367-1:2011 Guidelines for assessing the adverse environmental impact of fire effluents - Part I: General, 2011. https://doi.org/10.3403/bsiso26367

[75] Blomqvist, P, Hertzberg, T., Tuovinen, H., Arrhenius, K., Rosell, L. (2007) Detailed determination of smoke gas contents using a small-scale controlled equivalence ratio tube furnace method, Fire and Materials, Vol. 31:8:495 https://doi.org/10.1002/fam.946

[76] Heal, M.R., Kumar, P. and Harrison, R.M. (2012) Particles, air quality, policy and health, Chemical Society Reviews, 41:6606-6630. https://doi.org/10.1039/c2cs35076a

[77] Stec, A.A., Hull, T.R., Lebek, J.A. and Purser, D.A. (2008) The effect of temperature and ventilation condition on the toxic product yields from burning polymers, Fire and Materials 32:49-60. https://doi.org/10.1002/fam.955

[78] Kaczorek, K., Stec, A.A., and Hull, T.R., (2011) Carbon Monoxide Generation in Fires: Effect of Temperature on Halogenated and Aromatic Fuels, Fire Safety Science, 10:253-263. https://doi.org/10.3801/IAFSS.FSS.10-253

[79] C. A. de Wit, (2002) An Overview of Brominated Flame Retardants In the Environment, Chemosphere, 46:583- 624. https://doi.org/10.1016/S0045-6535(01)00225-9

[80] Shaw SD, Blum A, Weber R, Kannan K, Rich D, Lucas D, Koshland CP, Dobraca D, Hanson S, Birnbaum LS. Halogenated Flame Retardants: Do the Fire Safety Benefits Justify the Risks? Reviews on Environmental Health 25(4) 261-305 (2011).

[81] DiGangi,j., Blum, A., Bergman, Å., de Wit, C.A., Lucas, D., Mortimer, D., Schecter, A., Scheringer, M., Shaw, S.D., Webster, T.F. (2010) San Antonio Statement on Brominated and Chlorinated Flame Retardants, Environmental Health Perspectives, 118(A):516-536

[82] Stockholm convention on persistent organic pollutants, Stockholm, 22 May 2001 (depositary notification) 2009, Adoption of amendments to annexes a, b and c, United Nations. 
[83] Sjödin A, Päpke O, McGahee EE, Focant J-F, Jones RS, Pless-Mulloli T, et al. (2008) Concentration of Polybrominateddiphenyl Ethers (PBDEs) in Household Dust From Various Countries. Chemosphere, 73:S131-6. https://doi.org/10.1016/j.chemosphere.2007.08.075

[84] Hull, T.R., Law, R.J., Bergman, Å., (2014) Environmental Drivers for Replacement of Halogenated Flame Retardants, Polymer Green Flame Retardants, 119-179. https://doi.org/10.1016/B978-0-44453808-6.00004-4

[85] Stec, A.A., Hull, T.R., Torero, J.L., Carvel, C., Rein, G., Bourbigot, S., Samym, F., Camino, G., Fina, A., Nazare, S., and Delichatsios, M., Effects of fire retardants and nanofillers on the fire toxicity, Fire and Polymers V - Materials and Concepts for Fire Retardancy, Ch 21, 342-366, ACS Symposium Series 1013, Oxford University Press, (2009).

[86] Hull, T.R., Hull, A.A. Stec, S. Nazare, (2009) Fire Retardant Effects of Polymer Nanocomposites, Journal of Nanoscience and Nanotechnology, 9:4478-4486. https://doi.org/10.1166/jnn.2009.M80

[87] Hu, W., Zhan, J., Wang, X., Hong, N., Wang, B., Song, L., Stec, A.A., Hull, T.R., Wang, J., Hu, Y. (2014) Effect of Functionalized Graphene Oxide With Hyper-Branched Flame Retardant On Flammability and Thermal Stability of Cross-Linked Polyethylene, Industrial and Engineering Chemistry Research, 53(8):3073-3083. https://doi.org/10.1021/ie4026743

[88] Hong, N., Song, L., Wang, B., Stec, A.A., Hull, T.R., Zhan, J., Hu, Y., (2014) Co-Precipitation Synthesis of Reduced Graphene Oxide/NiAl-layered Double Hydroxide Hybrid and Its Application in Flame Retarding Poly(methyl methacrylate), Materials Research Bulletin, 49:657-664. https://doi.org/10.1016/j.materresbull.2013.09.051

[89] Hong, N., Zhan, J., Wang, X., Stec, A.A., Hull, T. R., Ge, H., Xing, W., Song, L., Hu, Y., (2014) Enhanced Mechanical, Thermal and Flame Retardant Properties by Combining Graphene Nanosheets and Metal Hydroxide Nanorods for Acrylonitrile-Butadiene-Styrene Copolymer Composite, Composites Part A: Applied Science and Manufacturing, 64:203-210. https://doi.org/10.1016/j.compositesa.2014.04.015

[90] Hong, N., Song, L., Hull, T.R., Stec, A.A., Wang, B., Pan, Y., Hu, Y. (2013), Facile Preparation of Graphene Supported Co3O4 and NiO For Reducing Fire Hazards of Polyamide 6 Composites, Materials Chemistry and Physics, 142(2-3):531-538. https://doi.org/10.1016/j.matchemphys.2013.07.048

[91] Jiang, S.-D., Bai, Z.-M., Tang, G., Song, L., Stec, A.A., Hull, T.R., Hu, Y., Hu, W.-Z. (2014) Synthesis of Mesoporous Silica@Co-Al Layered Double Hydroxide Spheres: Layer-by-layer Method and Their Effects On the Flame Retardancy of Epoxy Resins, ACS Applied Materials and Interfaces, 6(16):14076-14086. https://doi.org/10.1021/am503412y

[92] Stec, A. A., and Hull, T.R., Assessment of fire toxicity from polymer nanocomposites, Fire Retardancy of Polymers: New Strategies and Mechanisms, Edited by T R Hull and B K Kandola, Chapter 25, p 405-418, Royal Society of Chemistry, Cambridge, UK, 2009.

[93] Zhang, Y., Li, X., Cao, Z., Fang, Z., Hull, T.R., Stec, A.A., (2015) Synthesis of Zinc Phosphonated Poly(ethylene imine) and Its Fire-Retardant Effect in Low-Density Polyethylene, Industrial and Engineering Chemistry Research, 54 (13):3247-3256. https://doi.org/10.1021/ie504200y

[94] Zhang, Y., Li, X., Fang, Z., Hull, T.R., Kelarakis, A., Stec, A.A. (2017) Mechanism of Enhancement of Intumescent Fire Retardancy By Metal Acetates In Polypropylene, Polymer Degradation and Stability, 136:139-145. https://doi.org/10.1016/j.polymdegradstab.2016.12.018

[95] Wu, Z., Yang, L., Zhan, J., Chen, Y., Zhou, X., Hu, Y., Stec, A.A., Hull, T.R. (2016) Experimental Study On Polystyrene With Intumescent Flame Retardants From Different Scale Experiments, Fire and Materials, 40 (1):18-26. https://doi.org/10.1002/fam.2251

[96] Zhang, Q., Zhan, J., Zhou, K., Lu, H., Zeng, W., Stec, A.A., Hull, T.R., Hu, Y., Gui, Z. (2015) The Influence Of Carbon Nanotubes On the Combustion Toxicity of PP/Intumescent Flame Retardant Composites, Polymer Degradation and Stability, 115:38-44. https://doi.org/10.1016/j.polymdegradstab.2015.02.010

[97] Christou, A., Stec, A.A., Ahmed, W., Aschberger, K., Amenta, V., A (2016) Review of Exposure and Toxicological Aspects Of Carbon Nanotubes, And As Additives To Fire Retardants In Polymers, Critical Reviews in Toxicology, 46 (1):74-95. https://doi.org/10.3109/10408444.2015.1082972 
[98] Jiang, S.-D., Song, L., Zeng, W.-R., Huang, Z.-Q., Zhan, J., Stec, A.A., Hull, T.R., Hu, Y., Hu, W.Z. (2015) Self-assembly Fabrication Of Hollow Mesoporous Silica@Co-Al Layered Double Hydroxide@Graphene And Application In Toxic Effluents Elimination, ACS Applied Materials and Interfaces, 7 (16): 8506-8514. https://doi.org/10.1021/acsami.5b00176

[99] Jiang, S.-D., Bai, Z.-M., Tang, G., Song, L., Stec, A.A., Hull, T.R., Zhan, J., Hu, Y. (2014) Fabrication of Ce-doped MnO2 Decorated Graphene Sheets For Fire Safety Applications Of Epoxy Composites: Flame Retardancy, Smoke Suppression And Mechanism, Journal of Materials Chemistry A, 2 (41):17341-17351. https://doi.org/10.1039/C4TA02882A

[100] Hu, W., Zhan, J., Hong, N., Hull, T.R., Stec, A.A., Song, L., Wang, J., Hu, Y. (2014) Flame Retardant Polystyrene Copolymers: Preparation, Thermal Properties, and Fire Toxicities, Polymers for Advanced Technologies, 25 (6):631-637. https://doi.org/10.1002/pat.3261

[101] Tewarson, A., (2004) Combustion Efficiency and Its Radiative Component, Fire Safety Journal, 39:131-141. https://doi.org/10.1016/j.firesaf.2003.07.004

[102] Crewe, R.J., Stec, A.A., Walker, R.G., Shaw, J.E.A., Hull, T.R., Rhodes, J., Garcia-Sorribes, T., (2014) Experimental Results of a Residential House Fire Test on Tenability: Temperature, Smoke and Gas Analyses, Journal of Forensic Sciences, 59:139-154. https://doi.org/10.1111/1556$\underline{4029.12268}$

[103] Crewe, R.J., Stec, A.A., Walker, R.G., Shaw, J.E.A., Hull, T.R., Rhodes, J., Garcia-Sorribes, T., Experimental Results of a Residential House Fire Test on Tenability: Temperature, Smoke and Gas Analyses, Journal of Forensic Sciences, 59, 139-154, 2014. doi: 10.1111/1556-4029.12268

[104] 2010 Fire Test Procedure Code, Maritime Safety Committee, (MSC 87/26/Add.3) Annex 34, Part 2 Smoke and Toxicity Test, International Maritime Organisation, London.

[105] EN 45545-2:2013 Railway applications - Fire protection on railway vehicles - Part 2: Requirements for fire behaviour of materials and components.

[106] Stec, A.A. and Hull, T.R. (2011) Assessment of the fire toxicity of building insulation materials, Energy and Buildings, 43:498-506 https://doi.org/10.1016/j.enbuild.2010.10.015

[107] Study to evaluate the need to regulate within the Framework of Regulation (EU 305/2011 on the toxicity of smoke produced by construction products in fires $(525 / \mathrm{GRO} / \mathrm{IMA} / 16 / 1131 / 9107)$ European Commission.

[108] Wikipedia Article on Colectiv Nightclub Fire https://en.wikipedia.org/wiki/Colectiv nightclub fire (accessed 23/01/2017)

[109] Rouen Fire: at least 13 dead in birthday disaster at bar in French city https://www.theguardian.com/world/2016/aug/06/rouen-explosion-at-least-13-dead-after-blast-andfire-at-bar-in-french-city-reports (accessed 23/01/2017).

[110] Hull, T.R., Brien, D. and Stec, A.A. (2016) Quantification of toxic hazard from fires in buildings, Journal of Building Engineering 8:313-318 https://doi.org/10.1016/j.jobe.2016.02.014

[111] Lelieveld, J., Evans, J.S., Fnais, M., Giannadaki, D., Pozzer, A., (2015) The contribution of outdoor air pollution sources to premature mortality on a global scale, Nature 525:367-371 https://doi.org/10.1038/nature15371

[112] Shaposhnikov, D., Revich, B. and Bellander, T. (2014) Mortality related to air pollution with the Moscow heat wave and wildfire of 2010, Epidemiology, 25(3):359-64 https://doi.org/10.1097/ede.0000000000000090 